\title{
KUUE (INTER)SUBJEKTIIVSUSPARTIKLI KASUTUS EESTI KEELE REGISTRITES
}

\author{
TIIT HENNOSTE, HELLE METSLANG, \\ KÜLLI HABICHT, KÜLLI PRILLOP
}

\begin{abstract}
Annotatsioon. Artiklis analüüsime partiklite vist, ilmselt, tegelikult, õnneks, kahjuks ja paraku kasutust suulises suhtluses, ilukirjanduslikus proosas, ajakirjanduses, teaduses, netivestlustes ja -kommentaarides. Uurime partiklite funktsioone, kasutussagedust eri registrites ja selle seost registrite ja konsituatiivsete teguritega. Materjal pärineb Keeleveebi, suulise keele ja netivestluste korpustest. Kirjeldavat statistikat kombineerime partiklite kvalitatiivse semantika ja pragmaatika analüüsiga. Analüüs näitab, et a) ainult vist ja tegelikult sobivad varem esitatud partiklite registrilise sageduse mustriga, ülejäänud partiklite sagedused varieeruvad vähe ega sobi mustrisse ning b) ainult partikli vist sageduste seletamiseks sobivad põhiosas varem välja toodud konsituatiivsed tegurid. Ülejäänud partiklite sageduse registrilise varieerumise seletamiseks lisasime uusi tegureid ja näitasime, et need mõjuvad ainult teatud partiklite puhul ja/või teatud registrites.
\end{abstract}

Võtmesõnad: eesti keel, korpuspragmaatika, partiklid, (inter)subjektiivsus, registrid, varieerumine

\section{Sissejuhatus}

Partiklid on rühm muutumatuid sõnu, millega kõneleja või kirjutaja väljendab teksti sisu ja suhtlussituatsiooniga seostuvaid suhtumisi, hinnanguid ja seoseid. Siinse artikli teemaks on kuue partikli kasutus eesti keele eri registrites. ${ }^{1}$ Valisime eesti keele korpuste põhjal (Kaalep, Muischnek 2002; ENC19) kolm kõige sagedasemat episteemilist ehk tõenäosuspartiklit: vist, ilmselt ja tegelikult, ning kolm hinnangu-hoiakupartiklit: õnneks, kahjuks ja paraku. Vaadeldavate partiklite valikul arvestasime uuritava

${ }^{1}$ Artikli valmimist on toetanud Euroopa regionaalarengu fond (Eesti-uuringute Tippkeskus) ja Eesti Teadusagentuur (projekt PRG341 „Pragmaatika grammatika kohal: subjektiivsus ja intersubjektiivsus eesti keele registrites ja tekstiliikides“). 
sõna ühemõttelisust episteemilise või hoiakupartiklina, piisavat esindatust korpustes ja kasutussageduste erinevust tekstiliikides.

Meie uurimisküsimused on: 1) milline on partiklite kasutussagedus eri registrites, 2) kas partiklite kasutussagedusel on süsteemne seos registritega ning 3) millised konsituatiivsed tegurid on kasutussagedusega seotud?

Uuritavateks registriteks on suuline institutsionaalne suhtlus ja argivestlus, ilukirjanduslik proosa, ajakirjandus, teadus ning argine netivestlus ja netikommentaarid.

\section{Taust}

Subjektiivsust käsitatakse kui kõneleja või kirjutaja hoiakute, arvamuste ja veendumuste väljendumist tekstis, intersubjektiivsust aga kui tekstis väljenduvat kuulaja või lugeja arvestamist ja kaasamist. Nende kahe lähenemisviisi vahel on kattuvusi, üleminekualasid ja eri tõlgendusvõimalusi, mistõttu käsitleme neid siinses uurimuses koos (inter)subjektiivsusena (vt nt Traugott 2003; Nuyts 2012; Valdmets, Habicht 2013; Narrog 2017). Uuringu taustana on olulised kaks suunda, milles partikleid käsitletakse erinevalt: (inter)subjektiivsuse ja registrite uuringud. Ühelt poolt uuritakse neis partiklite kasutussagedusi, teiselt poolt sagedusega seotud konsituatiivseid tegureid.

\subsection{Partiklite kasutuse uuringud: sagedus}

(Inter)subjektiivsuse uuringutes on partiklid ja ka nende sagedus üks keskseid uurimisobjekte (nt Fitzmaurice 2004; Fanego 2010; Traugott 2010; Degand, Simon-Vandenbergen 2011; Waksler 2012; House 2013), samas leidub vähe töid, milles tegeletakse just selliste partiklitega, mis on esindatud meie uuringus (nt Piórkowska 2017). Lisaks keskendub suurem osa uurimistöödest konkreetsetele väljendusvahenditele ja vaatleb neid kindlas kitsas kontekstis, ühes tekstiliigis/žanris. Nii on näidatud, et saksa- ja venekeelsetes sotsioloogia konverentsiettekannetes kasutatakse partikleid mitu korda sagedamini kui sama valdkonna artiklites (Breitkopf-Siepmann 2012) ning markerite valik ja sagedus võivad erineda ka sama teksti osades, nagu teadusartikli resümees ja sissejuhatuses (Pho 2012). Laiemat konteksti arvestavates (inter)subjektiivsuse uuringutes käsitletakse võrdlevalt ennekõike suulist ja kirjalikku keelekasutust. Siin 
kinnitavad erinevad järeldused üldist tendentsi, et partikleid/markereid esineb kõnes rohkem kui kirjas (nt Haselow 2012; Aijmer 2013).

Registrite ja/või tekstitüüpide uuringutes võrreldakse eri keelevariante, huvitudes paljude keeleliste tunnuste komplektidest. Selle rühma uurimuste olulised mõisted on tekstiliik/žanr, register ja tekstitüüp, mida on eri uurimiskoolkondades käsitletud väga erinevalt (vt nt Hennoste 2000: 15-22; Biber, Conrad 2009: 1-25; Jonsson 2015: 34-37; Reinsalu 2019: 14-31). Siinses artiklis on neist tähtis register. Register on allkeel, mis seostub teatud suhtlusolukorra ja sellega seotud suhtluseesmärkidega. Registri määratlemisel lähtutakse sellest, et keelelisi valikuid mõjutavad või on nendega korrelatsioonis suhtlusolukorra erinevad omadused ja nendega täidetavad suhtluseesmärgid (suuline või kirjalik keelekasutus, argine või ametlik suhtlusolukord, otse- või telefonisuhtlus jne). Registrile on omased suhtlusolukorrast mõjutatud ja seda teistest registritest eristavad keeleliste tunnuste kimbud. Tavalised registrid on näiteks spontaanse argisuhtluse keel, asjaajamiskeel, teaduskeel. Registrid ei moodusta lõplikku loendit ja võivad olla väga avarad (nt argikeel) või ka väga kitsad (nt arsti-patsiendi vestluse keel). (Pikemalt vt nt Biber, Conrad 2009: 6-23; Hennoste, Pajusalu 2013: 38-50; Prillop jt 2021.)

Registriuuringutes ei analüüsita partikleid ükshaaval, vaid rühmana ja muude keelevariante eristavate markerite seas. Meid huvitavad partiklid võetakse tavaliselt kokku emfaasi (ingl emphatics, nt just, really) ning ebamäärasust ja ebaselgust väljendavate markerite all (ingl hedges, nt and so on, something like). Järgnevalt vaatame mõnda siinse teema seisukohast olulist teedrajanud uurimust.

Wallace L. Chafe on võrrelnud oma uurimustes lõunalauavestlusi, akadeemilisi loenguid, erakirju ja teadustekste (Chafe 1982; Chafe, Danielewicz 1987). Ta toob välja ennekõike suulist ja kirjalikku keelekasutust eristavad keelejooned ning näitab, et suulisele keelekasutusele (vestlused ja loengud) on mh iseloomulikud ka emfaatilised partiklid ja ebamäärasuse väljendajad.

Douglas Biber (1988, $1995 \mathrm{jm})$ on võrrelnud oma uurimustes paljusid tekstiliike/žanre. Meid huvitavad tekstid jagunevad tema klassifikatsiooni põhjal emfaatilisuse ja ebamäärasuse markerite seisukohast kolme rühma (vt Biber 1988: 102-103). Enim markereid kasutab suuline argivestlus, sagedusrea keskel paiknevad tema uurimuses institutsionaalset suulist suhtlust esindavad intervjuud ning vähim markereid kasutav skaalaots 
moodustab sujuva kontiinumi, milles ühel pool paikneb ilukirjanduslik proosa, teisel pool mh trükiajakirjandus ja teadus.

21. sajandil on kirjalik keelekasutus jagunenud trükis ja netis levivateks tekstideks. Osa neti vahendusel liikuvatest tekstidest on varasemad trükitekstid või nende analoogid, millesse tehnoloogia on lisanud kasutusvõimalusi, kuid milles puuduvad olemuslikud keelelised erinevused trükitekstidest. Teise osa moodustavad uued tekstiliigid: meilid, netikommentaarid, chat'i lühivestlused, reaalajas netivestlused, jututubade tekstid, Facebooki kommentaarid ja laigid, Twitteri minitekstid jne. Sellised tekstid ühendame netikeele registrirühmaks, millele on omased vähemalt kaks tunnust:

a) tekstid on loodud neti tarvis ja levivad netis;

b) tekstide funktsioone ja eripära mõjutavad tugevalt netisuhtluse situatiivsed erijooned, mis eristavad netitekstide loomise situatsiooni tavaliste trükitekstide ja suuliste tekstide omast.

Keeleliselt eristavad netitekste ennekõike sagedased suulise keele jooned ning just neti tarvis loodud uued keelevahendid ja võtted (vt Crystal 2006; Baron 2008; Herring jt 2013).

Ka netitekstide uurimused on toonud markerite hulgas esile meid huvitavad partiklid. Põhjalikem ja varasemate uurimustega ühilduvaim töö on Ewa Jonssonilt (2015), kes paigutab kaks netitekstide rühma Biberi kasutatud dimensioonidesse. Ühe rühmana vaatleb ta netivestlust (split-window ICQ Chat) ja teisena chat'i lühivestlusi. Jonssoni uurimuse järgi paigutub netivestluse keelekasutus (sh partiklikasutus) silmast silma argivestluse lähedusse ning lühivestlus jääb argivestluse ja institutsionaalse suulise suhtluse vahele (Jonsson 2015: 214).

Kokkuvõttes on kõigi lähenemisviiside tulemused omavahel kooskõlas. Esiteks näitavad uurimused, et emfaasi ja ebakindlust väljendavate partiklite sagedus on seotud kõige üldisemalt suulise ja kirjaliku pearegistriga ning selle sees neti- ja trükiregistrirühmadega. Konkreetselt esineb neid partikleid enim suulises argivestluses ja argises netivestluses. Teise keskme moodustab meid huvitavate registrite seas institutsionaalne suuline suhtlus. Kolmandasse keskmesse jäävad ilukirjanduslik proosa, teadus ja ametisuhtlus (Biberi mudelis ilukirjandus, uudisajakirjandus ja akadeemiline proosa). Seal on partikleid kasutatud kõige vähem. ${ }^{2}$

2 Ka Alice Luik (2020: 20-21) ja Kelly Virroja (2020: 35) on oma bakalaureusetöödes (küll väga väikese materjali põhjal) näidanud, et eestikeelsetes blogitekstides ja 


\subsection{Konsituatiivsed tegurid}

(Inter)subjektiivsuse ja registriuuringute teise poole moodustab küsimus, millised konsituatiivsed tegurid mõjutavad partiklite valikut ja kasutussagedust. Nagu eelnevas osutatud, on keskseim erinevus suulise ja kirjaliku pearegistri vahel. Samas tõid Biberi ja Jonssoni uuringud esile, et see piir ei ole tekstiliikide seisukohast päris are. Nii kuuluvad nt erakirjad samasse rühma spontaansete kõnede ja intervjuudega (Biber 1988: 128) ning netivestlused suuliste vestlustega (Jonsson 2015: 214). See näitab, et partiklikasutust mõjutavad kitsamad tegurid ${ }^{3}$ kui laialt määratletud register.

Oluline eristaja on eri terminitega iseloomustatud tegur, mis näitab, kui palju on teksti koostajal aega ja võimalusi teksti redigeerida (nt Chafe 1982). Tegu on skaalaga, mille ühes otsas paiknevad reaalajas loodud ehk spontaansed tekstid ning teises otsas tekstid, mille tegemisel ajasurve puudub ning mida on võimalik vabalt redigeerida. Reaalajas loodud teksti näiteks on suuline vestlus, milles teksti tegijal on minimaalselt aega. Lisaks on tähtis, et kõneleja saab keskenduda oma mälus ainult sellele üksusele, mida ta produtseerib, ning suulise teksti lenduvus ei võimalda väljaöeldut hiljem näha ega muuta. Skaala teises otsas on nt teadus- või ilukirjandustekstid, mille loomisel aja- ja mälupiirangud puuduvad ning tegija saab valmis tekstis vabalt tagasi liikuda. Muud siin vaadeldavad kirjalikud tekstirühmad jäävad ajapiirangutelt skaala kahe otsa vahele. Netivestlused toimuvad reaalajas, kuid kirjutajal on rohkem aega oma teksti koostamiseks kui suulises vestluses kõnelejal. Netikommentaarid ei nõua reaalajas koostamist. Ajakirjandusteksti tegijal on aega rohkem kui netikommentaatoril, kuid kindlasti vähem kui teadus- või ilukirjandusteksti loojal.

Teine oluline tegur on suhtlejate koostöö või nende eraldatus teksti tegemisel ehk teksti ehitamise dialoogiline või monoloogiline loomus. Skaala ühes otsas on siin suuline suhtlus, mis on loomult dialoogiline. Partner saab anda kõnelejale jooksvat tagasisidet ja kõneleja seda oma

televisiooni poliitilise vestlussaate materjalis leidus episteemilisi markereid rohkem kui ajakirjandus- ja ilukirjandustekstides.

3 Tuleb meeles pidada, et samadest nähtustest on eri uurijad kõnelnud tihti erinevate terminitega. Ülevaadet varasematest uurimustest vt Hennoste 2000; Jonsson 2015; vt ka Chafe 1982; Biber 1988, 1995; Rühlemann 2007; Biber, Conrad 2009; Hennoste, Pajusalu 2013. 
teksti tegemisel jooksvalt arvestada, samuti saavad suhtlejad luua teksti otseses mõttes koos, nt lõpetades üksteise lausungeid. ${ }^{4}$ Skaala teises otsas on loomult monoloogilised tekstid, milles looja ja vastuvõtja dialoog teksti loomisel puudub. Selle näiteks on kirjalikud trükitekstid ja netikommentaarid. Nende vahele jääb netivestlus, mis erineb suulisest vestlusest selle poolest, et seal ei ole jooksev tagasiside võimalik, kuid on võimalik saadetiste vaheline tagasiside ning partnerite koostöö lausungite tegemisel.

Tähtis tegur on ka eri terminitega iseloomustatud skaala, mille ühes otsas on kaasatuslik ja teises otsas informatiivne sisu (ingl involved vs. informational production, Biberi terminid). Kaasatusliku sisu all peetakse silmas teksti, mida iseloomustab ühelt poolt autori tihe seotus oma tekstiga, tunnete ja hoiakute väljendamine, teiselt poolt ka tihe seotus partneriga. Sellisena on kaasatus otseselt seotud subjektiivsuse ja intersubjektiivsusega (nt Marin-Arrese 2007; Mortensen 2012). Informeerimine on lai tegevuste ring, mille alla kuuluvad seletamine, argumenteerimine, direktiivide ja juhiste andmine jne. Neis on kesksel kohal faktide esitamine ning välditakse autori eksplitsiitset kaasatust, tema hoiakute ja emotsioonide väljendamist. Kaasatuslikku skaalaotsa kuuluvad argivestlused, netivestlused, netikommentaarid, maksimaalselt informatiivsesse otsa jääb teadus. Teaduse lähedusse paigutuvad ajakirjandus ning institutsionaalne suuline suhtlus. Omaette jääb ilukirjandus, mis on ennekõike kaasav, kuid vahendab peale autori hoiakute ja tunnete ulatuslikult ka tegelaste omi (neid esineb ka ajakirjanduses, kuid palju vähem).

Ennekõike suulise suhtluse puhul on tähtsa tegurina nimetatud jagatud konteksti (ingl shared context). Selle mõiste alla koondatakse tavaliselt kaks nähtust (nt Rühlemann 2007: 49). Üks piir eristab eeskätt argivestlust ja institutsionaalset suulist suhtlust. Argivestluses on suhtlejatel üksteise kohta palju ja detailset infot, mis lubab jätta asju ütlemata või väljenduda lühidalt, kasutada üldiseid või ebatäpseid määratlusi jne. Institutsionaalses suhtluses sellised teadmised puuduvad või on vähesed ning tekst peab olema eksplitsiitsem ja täpsem. Teine piir eristab silmast silma ja vahendatud suhtlust. Silmast silma suhtlejatel on kasutada mitteverbaalsed vahendid (žestid, näoilmed jms), mis võimaldavad jätta osa infost verbaalselt väljendamata või kasutada seal üldisi, kaudseid,

${ }^{4}$ Artiklis oleme läbiva põhiterminina kasutanud lausungit, millena käsitame tekstiüksust, mis grammatiliselt võib olla nii liitlause, lihtlause, fraas kui ka üksiksõna. 
ebaselgeid viiteid. Vahendatud suhtlus nõuab ka siin eksplitsiitseid ja täpseid verbaalseid vahendeid. Skaala ühes otsas eristub suuline silmast silma suhtlus ja teises otsas kirjalik trükisuhtlus. Nende vahele paigutub netisuhtlus, milles kasutatakse mitteverbaalsete vahenditena emotikone, mille üks (kuid mitte ainus) roll on emotsioonide ja hoiakute väljendamine. Samas esineb emotikone palju netivestluses, kuid väga vähe netikommentaarides.

Järgmine liigendaja on suhtlussfäär. Suuline register jagatakse uuringutes traditsiooniliselt kaheks: argivestluseks (ingl everyday/ordinary conversation) ja institutsionaalseks suhtluseks (ingl institutional interaction). Institutsionaalses suhtluses on vähemalt üks suhtlejatest mingi institutsiooni esindaja ning tekstide ehitust mõjutavad vastava institutsiooni suhtluse normid (nt arsti-patsiendi suhtlus, müüja-ostja suhtlus).

Avalikult levivate trüki- ja netitekstide puhul institutsionaalsuse mõistet ei kasutata. Üldisemalt võib need registrid jagada kaheks. Ühe osa moodustavad siin institutsionaalse suulise registriga analoogilised ametlikud registrid. Siia kuuluvad mh ajakirjandus ja teadus, kus kirjutaja esindab kindlat institutsiooni ja järgib seal kehtivaid tekstiehituse norme. Teise osa moodustavad registrid, milles osalejad ei esinda institutsiooni ja kus tekstide ehitamise normid on vabamad. Siia kuuluvad mh netikommentaarid ja ilukirjanduslik proosa. Seda nimetame avalikuks registriks.

Teisalt jagunevad kirjalikud tekstid mitmesse retoorilisse tüüpi, millest siin on tähtis jaotus jutustavate ja seletavate tekstide vahel. Jutustavaid (narratiivseid) tekste esindab ilukirjanduslik proosa, seletavate tekstide iseloomulikuks esindajaks on teadus. Nende vahele jäävad jutustamist ja seletamist kombineerivad tekstid, mille hulka kuulub nt ajakirjandus.

Kokkuvõttes saame välja tuua osalt eri terminitega käsitletud tegurite skaalad, millega partiklite kasutuse sagedust on seostatud (tabel 1):

- teksti tegemise spontaansus vs. redigeerimise võimalus,

- suhtluse dialoogiline vs. monoloogiline loomus,

- kaasatus vs. informeeriv sisu,

- silmast silma suhtlus vs. vahendatud suhtlus,

- argine $v s$. avalik vs. ametlik (institutsionaalne) suhtlus,

- vestlus vs. jutustav vs. seletav tekstitüüp. 
Tabel 1. Tekstiliikide konsituatiivsed tegurid seniste uurimuste põhjal

\begin{tabular}{|l|c|c|c|c|c|c|}
\hline Registrid & $\begin{array}{c}\text { Vestlus/ } \\
\text { jutustus/ } \\
\text { seletus }\end{array}$ & $\begin{array}{c}\text { Dialoog/ } \\
\text { monoloog }\end{array}$ & $\begin{array}{c}\text { Spon- } \\
\text { taanne/ } \\
\text { redigeeri- } \\
\text { tud }\end{array}$ & $\begin{array}{c}\text { Kaasa- } \\
\text { tus/ } \\
\text { info }\end{array}$ & $\begin{array}{c}\text { Silmast } \\
\text { silma/ } \\
\text { vahen- } \\
\text { datud }\end{array}$ & $\begin{array}{c}\text { Argine/ } \\
\text { avalik/ } \\
\text { ametlik }\end{array}$ \\
\hline Argivestlus & $\mathrm{V}$ & $\mathrm{D}$ & $\mathrm{SP}$ & $\mathrm{KA}$ & $\mathrm{S} / \mathrm{V}$ & $\mathrm{AR}$ \\
\hline Netivestlus & $\mathrm{V}$ & $\mathrm{D})$ & $\mathrm{SP}$ & $\mathrm{KA}$ & $\mathrm{V}$ & $\mathrm{AR}$ \\
\hline $\begin{array}{l}\text { Institut- } \\
\text { sionaalne } \\
\text { suhtlus }\end{array}$ & $\mathrm{V}$ & $\mathrm{D}$ & $(\mathrm{SP})$ & $\mathrm{IN}$ & $\mathrm{S} / \mathrm{V}$ & $\mathrm{AM}$ \\
\hline $\begin{array}{l}\text { Neti- } \\
\text { kommentaar }\end{array}$ & $\mathrm{V}$ & $\mathrm{M}$ & $(\mathrm{SP})$ & $\mathrm{KA}$ & $\mathrm{V}$ & $\mathrm{AV}$ \\
\hline Ilukirjandus & $\mathrm{J}$ & $\mathrm{M}$ & $\mathrm{RE}$ & $\mathrm{KA}$ & $\mathrm{V}$ & $\mathrm{AV}$ \\
\hline $\begin{array}{l}\text { Aja- } \\
\text { kirjandus }\end{array}$ & $\mathrm{S} / \mathrm{J}$ & $\mathrm{M}$ & $\mathrm{RE}$ & $\mathrm{IN}$ & $\mathrm{V}$ & $\mathrm{AM}$ \\
\hline Teadus & $\mathrm{S}$ & $\mathrm{M}$ & $\mathrm{RE}$ & $\mathrm{IN}$ & $\mathrm{V}$ & $\mathrm{AM}$ \\
\hline
\end{tabular}

* Tabelis on konsituatiivsed tegurid tähistatud veeru päises olevate sõnade ühe või kahe algustähega.

\section{Materjal ja meetod}

Uuritav materjal on võetud portaali Keeleveeb korpustest, „Suulise eesti keele korpusest" ja kahest projekti PRG341 töörühma korpusest: netivestluste korpusest, mis sisaldab aastatel 2010-2020 kogutud Skype'i, Messengeri jms vestlusi, ja teadustekstide korpusest, mis sisaldab nii humanitaar- kui ka reaalteaduslikke artikleid ning doktoritööde eestikeelseid kokkuvõtteid aastaist 2010-2020. Kokku valisime uurimiseks seitse korpust, mis koonduvad kolme registrirühma. (Korpuste kohta vt ka Prillop jt 2021.)

I. Trükitekstid
a. ilukirjanduslik proosa $(5,77$ miljonit tekstisõna)
b. ajakirjandus (120 miljonit)
c. teadus (499 000)

II. Netitekstid
a. netivestlused (95 000)
b. netikommentaarid (1,9 miljonit) 
III. Suulised tekstid
a. institutsionaalne suhtlus (312 000)
b. argivestlus (240 000)

Valitud suulised ja trükitekstid esindavad traditsioonilisi registreid, mida on kasutatud paljudes varasemates uurimustes. Suulisest registrist vaatleme argivestlust ja institutsionaalset suhtlust. Trükitekstide registris on avalikke tekste esindav ilukirjanduslik proosa (ilukirjandus) ning ametlikke tekste esindavad ajakirjandus ja teadus. Nende kõrvale oleme valinud kaks netiregistri tekstide rühma, mis võimaldavad võrdlust suuliste ja trükitekstidega.

Netitekstide liigitus on olnud väga heterogeenne ja ebasüsteemne. Meie uurimuses on kõigepealt välja toodud (argine) spontaanne netivestlus (ing1 instant messaging, IM), mis on suulise argivestluse netianaloog (Baron 2013; Hennoste, Pajusalu 2013: 89-94). Suulisest argivestlusest eristavad teda kirjalikust vormist ja netisuhtluse tehnoloogiast mõjutatud jooned.

- Kirjaliku netiteksti tegemise tempo on suulise teksti omast palju aeglasem.

- Suuline tekst liigub suhtlejate vahel voolavalt, häälikhaaval, netisuhtluses aga saadetiste (ingl post) kaupa.

- Suuline tekst on lenduv, netisaadetis säilib peale lõpetamist.

- Suulises suhtluses on kuulajal võimalik anda kõnelejale vooru ajal jooksvat tagasisidet, netivestluses mitte.

- Suulises suhtluses on normiks keskendumine ühele vestlusele ja partnerile, netisuhtluses on tavaline rööprähklemine.

Teine uurimiseks valitud tekstirühm on veebiportaalides meediatekstidele lisatavad netikommentaarid (Hennoste 2008: 346-349; Hennoste jt 2010). Kommentaarid eristuvad ühelt poolt netivestlusest ja teiselt poolt netis levitatavatest ajakirjandustekstidest.

- Kommentaarid ei ole iseseisvad tekstid. Nad suhtlevad osalt lähtetekstiga, esitades selle kohta tavaliselt arvamusi, hinnanguid, täiendusi jms, lisaks tekivad kommenteerijate vahel spontaansed minidialoogid. Siin on tegu küll dialoogilise suhtlusega, kuid mitte dialoogiga vestluse mõttes. Teisalt erinevad kommentaarid ajakirjandustekstidest, mis üldjuhul on iseseisvad tekstid ega ole dialoogi osad.

- Erinevalt netivestlusest puudub netikommentaari autoril kohustus reageerida lähtetekstile või teise kommenteerija postitusele reaal- 
ajas. Sellisena on kommenteerijal rohkem aega oma teksti toota kui netivestlejal. Siiski on tegu valdavalt spontaansete tekstidega, mis sellisena erinevad redigeeritud ajakirjandustekstidest.

- Kommentaarid on avalikud tekstid, samas esinevad kommentaatorid enamasti pseudonüümide all. See eristab kommentaare argistest ja nimelistest netivestlustest ning ametlikest ja üldjuhul nimelistest ajakirjandustekstidest.

- Erinevalt netivestlustest ja ajakirjandustekstidest on kommentaaridel moderaator, kellel on õigus tekste kustutada.

Kokkuvõttes iseloomustab valitud tekstirühmi tabel 2.

Tabel 2. Uuritavad tekstirühmad

\begin{tabular}{|l|c|c|c|}
\hline Suhtlussfäär & Suuline register & Netiregister & Trükiregister \\
\hline Argine & argivestlus & netivestlus & - \\
\hline Avalik & - & netikommentaar & ilukirjandus \\
\hline Ametlik & $\begin{array}{c}\text { institutsionaalne } \\
\text { suhtlus }\end{array}$ & - & $\begin{array}{c}\text { ajakirjandus } \\
\text { teadus }\end{array}$ \\
\hline
\end{tabular}

Järgnevas analüüsiosas kasutame termineid argivestlus, institutsionaalne suhtlus, netivestlus, netikommentaar, ilukirjandus, ajakirjandus ja teadus.

Analüüsis kombineerisime kirjeldavat statistikat kvalitatiivse semantilise ja pragmaatilise analüüsiga. Kõigepealt tegime korpustes esindatud kasutusjuhtude kvalitatiivse analüüsi, täpsustasime partiklite tähendust ja funktsioone, leidsime partiklite tüüpilised kasutuskontekstid ja positsioonid lausungis. Seejärel analüüsisime partiklite kasutussagedusi registrites statistiliselt, et leida registritevahelisi sarnasusi ja erinevusi, ning registrite rühmitumist partiklite kasutussageduse järgi. Järgnevas kvalitatiivses analüüsis otsisime seoseid registrite konsituatiivsete tegurite ning partiklite semantika ja pragmaatika vahel. ${ }^{5}$

5 Täname materjali esmases analüüsis osalenud projekti PRG341 töörühma liikmeid Kirsi Laanesood, David Ogreni, Liina Pärismaad, Elen Pärti, Andra Rummi, Andriela Rääbist ja Carl Eric Simmulit. 


\section{Partiklite semantika ja pragmaatika}

Selles jaotises anname ülevaate partiklite semantikast ja pragmaatikast. Lähtume EKSSi ja Sõnaveebi määratlustest ning täpsustame neid varasemate uurimuste ja oma materjali põhjal, seejärel toome välja partiklite tüüpilised kasutuskontekstid ja positsioonid lausungis.

\subsection{Episteemilised partiklid}

Esimese rühma moodustavad episteemilised partiklid vist, ilmselt ja tegelikult.

Vist väljendab EKSSi järgi oletust ning Sõnaveebi järgi „osutab võimalusele, milles ollakse küllaltki, kuid mitte päris kindel; suure tõenäosusega“. Partikli vist sünonüümid on arvatavasti, ilmselt, tõenäoliselt, võib-olla. Samal ajal liigitavad muud allikad partikli vist keskmise tõenäosuse markeriks (EKG II: 188; Kehayov 2009: 173). Ka meie analüüs näitab, et vist on ebakindlat teadmist markeeriv laia kasutusega partikkel, mille puhul ei saa välja tuua suure tõenäosuse väljendamist.

Partikli vist valitsev asukoht on lausungi sees oma mõjuala ees (1), harva esineb ta ka teistes positsioonides: nii mitmeosalise lausungi teise osalause alguses (2), lausungi absoluutses alguses (3), lõpus (4) kui ka lausungi järel omaette jätkuna (inkremendina) (5).

(1) aga `nüüd nad vist (.) kont’rollisid=õõ (.) `õpilased ma=mõtlen, (SUUL ARGI)

(2) Sellest ei olnud küll kirjutises lugeda, aga vist oli arst selle käe ravimisel tubli. (AJA)

(3) Vist on madalrõhkkond tulemas, vägisi kipub unele :-))) (KOMM)

(4) „Aga see tibi, kes siin elas, sul jäi mingi jutt pooleli vist.“(ILU)

(5) kiisukesele oli arsti installeerinud - ajutiselt ja uuringuteks, aga nüüd õnneks ka eemaldanud. vist. (KOMM)

Partikli vist oluline erijoon seisneb selles, et ta esineb teistest uuritavatest partiklitest umbes kaks korda rohkem küsimustes (6) ja vastustes (7). Sealjuures esineb vist ennekõike kinnitusküsimustes, muu hulgas ka väitlausungiga vormistatud küsimuse lõpus sekundaarse küsimarkerina (Hennoste jt 2016). 
(6) $01 \mathrm{H}$ : tere. kauplus Eu 'roniks see on 'Tsepelinis vist.

$02 \mathrm{~V}$ : jaa? üks='hetk, (SUUL IN)

(7) „Kus? Töökojas vist,“ kohmab mees. (ILU)

Ilmselt on Sõnaveebi järgi sõnade vist, arvatavasti ja tõenäoliselt sünonüüm. Süntaksikäsitlustes (EKG II: 188; Kehayov 2009: 173) loetakse seda suure tõenäosuse markeriks (8), nagu ka näiteks partiklit tõenäoliselt (9). Ka meie analüüsi järgi väljendab ilmselt suuremat tõenäosust kui vist. Vist on omamoodi baaspartikkel: selle asemel partiklit ilmselt kasutades võimendab kasutaja oma hinnangut fakti või sündmuse tõenäosusele (vrd nt Ta on vist töökojas ja Ta on ilmselt töökojas). ${ }^{6}$

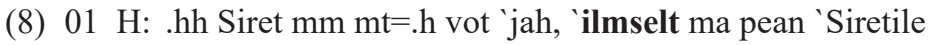
helistama=ja ta 'välja

02 ajama.

$03 \mathrm{~V}: \mathrm{mhmh}$ ? (SUUL ARGI)

Teisalt on oluline asjaolu, et ilmselt jaguneb EKSSi järgi kaheks tähendusrühmaks: a) 'silmanähtavalt, selgesti, kindlalt'; b) 'nagu näha, küllap'. Esimene variant esindab adverbilist tähendust, millest paistab läbi seos omadussõnaga ilmne. Teises tähenduses on tegu esimesest kujunenud episteemilise partikliga, milles sisaldub eelmisest astmest kaasa tulnud leksikaalne seos omadussõnaga ilmne ja selle tähendusega 'silmanähtav', mis ühtlasi viitab, et sõnaga iseloomustatu toetub millelegi tõendatavale, on kuidagi põhjendatud (9). See komponent partiklil vist puudub (vrd süvariigil on ilmselt mitu nägu ja süvariigil on vist mitu nägu).

(9) Laneman: süvariigil on ilmselt mitu nägu.

„Aga süvariigil on tõenäoliselt mitu nägu. Enamasti neist peetakse silmas eriteenistusi, siseministeerium on ka tõenäoliselt see koht.“(AJA)

${ }^{6}$ Lugeja või kuulaja vaatenurgast tehtud eksperimentaalsest uuringust partiklitega arvatavasti, äkki ja võib-olla (Tüüts, Argus 2016) saab järeldada, et tõenäosushinnangu erinevused partiklite vahel on püsivad ja neid ei saa sünonüümideks lugemisega kaotada. Vastuvõtja hinnang partikliga väljendatava tõenäosuse üldisele astmele võib küll konsituatsiooniti varieeruda, kuid partiklite omavaheline suurema või väiksema tõenäosushinnangu suhe püsib (partikliga arvatavasti väljendatavat tõenäosust tajuti igal juhul suuremana kui partiklil äkki, mis omakorda oli veidi suurema tõenäosuse marker kui võib-olla). 
Põhiliselt paikneb ka ilmselt lausungi sees enne mõjualust osa (10) ning harva lausungi lõpus (12) või järel (13). Selle kõrval esineb ta palju sagedamini kui vist lausungi absoluutses alguses (11) ja ka lausungi sees teise osalause alguses, kuid mitte küsisõna rollis.

(10) Ka metallitoodete tootmine on ilmselt seotud tihedalt kodumaise majanduskonjunktuuriga. (TEA)

(11) Ilmselt oli Arturit tulistatud metsast, selja tagant. (ILU)

(12) $\mathrm{K}$ : väga lahe on, aga tohutult õppida ka istun ülikooli raamatukogus õhtuti L: ooo, mis kellaaegadel K: homme kella ühest täitsa õhtuni ilmselt. (NV)

(13) Et nüüd tuleb ka vastav pikem tiraad minu kohta ... ilmselt. (KOMM)

Partikli tegelikult tuumtähendus on EKSSi järgi 'tõeliselt, tegelikkuses, päriselt' ning Sõnaveebis '(täiel määral) tegelikkuses, reaalsuses, mitte näiliselt'. Tähendus viitab, et ütleja ei sea haaratava info tõelevastavust kahtluse alla, ning sõna tegelikult sünonüümidena on nimetatud sõnu päriselt ja tõeliselt. Sõnaveebis on lisatud sõna tegelikult partikliline kasutus, mis ,pehmendab otseütlemist, aga kinnitab väidet: sama hästi kui, peaaegu, enam-vähem", ning tema sünonüümid on õigupoolest, tõttöelda, õieti. ${ }^{7}$

Meie materjalis (ka kujud tegelt, tglt) on esindatud mõlemad Sõnaveebis mainitud variandid. Samas näitab analüüs, et üldjuhul on tegelikult kasutusel kontekstis, kus ta toob esile mingi vastanduse eelneva infoga. Tegelikult viitab ennekõike millelegi, mis on tõsikindel erinevalt varem teatust või arvatust, lükkab ümber ootust, parandab, täpsustab ja annab episteemilise hinnangu (14). Ka tähenduses 'õigupoolest' toob ta esile asjaolu, mis on ootamatu või üllatav vastandina sellele, mida kasutaja varem teadis või ootas (15). Kui ümber lükatakse vestluskaaslase ootus, toimib tegelikult intersubjektiivsena (16). Positsioonilt paikneb ka tegelikult valdavalt lausungi sees (17). Selle kõrval esineb ta samal määral kui ilmselt ka lausungi absoluutses alguses (15) ja lausungi sees teise osalause alguses, muudes positsioonides harva $(14,16,18)$.

\footnotetext{
7 Partiklina paistab tegelikult olevat kujunemisstaadiumis, sest määrsõnalised (leksikaalsed) kasutusjuhud ja partikli kujunemist näitavad sildkontekstid on keelekasutuses nähtaval ning tähendused on omavahel tihedalt seotud. Annika Küngase andmetel on tegelikult sadakonna aasta jooksul kirjakeeles pragmaatilist kasutust sujuvalt laiendanud. Sellega on kaasnenud tema kasutussageduse suurenemine (Küngas 2014: 33).
} 
(14) Ka siis, kui muusika seisab, ta tegelikult liigub väga kiiresti. (AJA)

(15) Tegelikult ma kartsin seal üksinda olla. (ILU)

(16) Ei, tegelt väikeses koguses on ta tore, aga muidu on suht ränk. (NV)

(17) Seega ütled, et sinu „RE pooldajad“ on tegelikult EKRE pooldajad? :D (KOMM)

(18) $01 \mathrm{~A}$ : aa `tead mida ma `tahaks tegelikult.

$02 \mathrm{E}:$ noo?

03 A: sa lubasid mulle `viiulit mängida. (SUUL ARGI)

\subsection{Hinnangu-hoiakupartiklid}

Teise uuritava rühma moodustavad hoiakupartiklid õnneks, kahjuks ja paraku. Neid eristab viitamine vastandlikele hoiakutele ning ühendab asjaolu, et nad eeldavad selle propositsiooni tõesust, mille kohta hoiakuid väljendatakse.

Õnneks osutab positiivset emotsiooni, väljendades EKSSi ja Sõnaveebi järgi 'kõneleja heakskiitvat v. tänulikku suhtumist; heameelt, rahulolu v. kergendustunnet mingi soovitud, meeldiva asjaolu puhul'. Meie materjalis esineb partikkel samal viisil $(19,20,21)$. Onneks paikneb suhteliselt võrdselt lausungi absoluutses alguses (19) ja sees $(20,21)$. Muudes positsioonides esineb ta harva.

(19) Õnneks on varsti nädalavahetus. (ILU)

(20) Tanel Padar meenutab: mul õnneks sai joomisest enne villand kui pillimängust (AJA)

Harv on kasutus, milles õnneks väljendab vastandust, asjaolu, et asjad on paremini, kui eeldati või oodati (21).

(21) $01 \mathrm{~V}$ : ei noh kui teil 'külmetand on siis 'küll ei tohi tulla. (1.0) 'põdege sis

02 `sääl olge `soojas=ja

$03 \quad(0.8)$

$04 \mathrm{H}$ : jah (.) `soe siin õnneks `on. (SUUL ARGI)

Kahjuks ja selle sünonüüm paraku väljendavad nii EKSSi kui ka Sõnaveebi järgi 'kõneleja kahetsevat suhtumist, kahjutunnet mingi soovimatu, ebameeldiva, paratamatu asjaolu puhul'. Meie materjal kinnitab seda tähendust. Samas näitab analüüs, et need sõnad esinevad peaaegu ainult kontekstides, milles sisaldub vastandus tegelikkuse ja oodatu vahel. 
Partiklid osutavad, et asjad on halvemini, kui eeldati või oodati, ning sellisena on neil lisaks kahetsev, vabandav münt. Ka need partiklid paiknevad suhteliselt võrdselt lausungi absoluutses alguses $(22,24)$ ja sees $(23,25)$.

(22) Iga aastaga kipub suurenema üliõpilaste hulk, kes mõne kursuse alguses tulevad pärast esimest loengut minu juurde ja ütlevad: „Kahjuks ma ei saa teie loengutes käia, sest mul on samal ajal töö.“ (AJA)

(23) $01 \mathrm{H}$ : .hhh ee: (.) kas te: 'olete veel ’aasta 'vahetusel `vaba.

$02 \quad(1.0)$

$03 \mathrm{~V}$ : ei aastavahetus on 'kinni kahjuks juba. (SUUL IN)

(24) Paraku kas väljendusin kehvalt, või oleme igaüks oma mõttemallis nii kinni, et ei saa üksteisest aru. (KOMM)

(25) Äriideena kukkus PEP paraku läbi. (AJA)

Partiklil paraku on peale negatiivse, kriitilise hoiaku väljendamise mõnes kasutuskontekstis säilinud ka algsest möönvas kõneviisis verbivormist lähtuv möönev tähendus (26), mis muudab ta vähem emotsionaalseks ning seega kasutatavaks ametlikumates ja neutraalsemates kontekstides kui kahjuks.

(26) Seega oleks lihtne öelda, et midagi tuleks piirata või maksustada. Paraku on lihtsatel lahendustel päriselus harva mõju. (AJA)

\subsection{Vahekokkuvõte}

Kokkuvõttes on vist kõige neutraalsemalt ebakindlust väljendav ja kõige laiema kasutusega partikkel. Ilmselt kajastab samuti ebakindlust, kuid on kitsama ja eripärase kasutusega. Ühelt poolt annab see edasi tugevamat kindlust öeldava tõelevastavuses kui vist ning teisalt seda, et öeldu on mingil moel põhjendatud. Tegelikult esineb kahes tähenduses, nii 'tõeliselt, tegelikkuses, päriselt' kui ka 'õigupoolest'. Õnneks väljendab positiivset ning kahjuks ja paraku negatiivset hoiakut.

Kõik partiklid esinevad lausungi kõigis positsioonides, sealjuures väga valdavalt oma mõjuala ees, harva selle järel. Asendi poolest erinevad episteemilised ja hoiakupartiklid. Episteemilised partiklid esinevad valdavalt lausungi sees oma mõjuala ees. Sealjuures on see partikli vist jaoks väga valitsev positsioon, samas ilmselt ja tegelikult paiknevad nii lausungi absoluutses alguses kui ka lausungi sees teise osalause alguses palju sagedamini. Onneks, kahjuks ja paraku esinevad lausungi sees ja alguses suhteliselt võrdselt ning muudes positsioonides harva. 
Partiklite kontekstid on osalt erinevad. Partikli vist erijoon on teistest partiklitest palju sagedasem esinemine küsimustes ja vastustes. Tegelikult, kahjuks ja paraku on kasutusel ennekõike lausungites, mis esitavad kuulaja või lugeja väidetele või ootustele vastanduvat infot. Seetõttu on nad oma põhiolemuselt intersubjektiivsed (vt Piórkowska 2017). Ülejäänud väljendavad aga üldjuhul pigem subjektiivsust (kõneleja või kirjutaja suhtumist lausungiga edastatavasse infosse), kuigi võivad konkreetsel kasutusjuhul toimida ka intersubjektiivsetena (suhestuda kaasvestleja suhtumise ja kaasatusega, väljendada küsivust vms).

\section{Partiklite kasutus eri registrites}

Siinses jaotises vaatleme partiklite registrilise kasutuse statistikat. Meie esmane küsimus on, milline on partiklite kasutussagedus uuritavates registrites. Tabelis 3 esitame võrdlevalt partiklite normaliseeritud sagedused eri registrites.

Tabel 3. Partiklite normaliseeritud sagedused 10000 sõne kohta

\begin{tabular}{|c|c|c|c|c|c|c|c|c|}
\hline \multirow{2}{*}{ 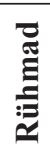 } & \multirow{2}{*}{ Registrid } & \multicolumn{3}{|c|}{$\begin{array}{c}\text { Episteemilised } \\
\text { partiklid }\end{array}$} & \multicolumn{3}{|c|}{$\begin{array}{c}\text { Hinnangu- } \\
\text { hoiakupartiklid }\end{array}$} & \multirow{2}{*}{ Kokku } \\
\hline & & vist & ilmselt & tegelikult & onneks & kahjuks & paraku & \\
\hline \multirow[t]{2}{*}{1} & $\begin{array}{l}\text { Argi- } \\
\text { vestlus }\end{array}$ & 26,7 & 2,3 & 14,4 & 0,9 & 0,2 & 0 & 44,5 \\
\hline & Netivestlus & 29,1 & 2,4 & 11,6 & 1,8 & 1,6 & 0,1 & 46,6 \\
\hline \multirow{3}{*}{2} & $\begin{array}{l}\text { Neti- } \\
\text { kommen- } \\
\text { taarid }\end{array}$ & 8,1 & 5,3 & 9,3 & 0,9 & 4,0 & 1,9 & 29,4 \\
\hline & $\begin{array}{l}\text { Institut- } \\
\text { sionaalne } \\
\text { suhtlus }\end{array}$ & 11,9 & 3,2 & 7,4 & 0,1 & 2,1 & 0,1 & 24,8 \\
\hline & $\begin{array}{l}\text { Ilukir- } \\
\text { janduslik } \\
\text { proosa }\end{array}$ & 7,0 & 4,1 & 6,2 & 1,4 & 0,8 & 0,8 & 20,3 \\
\hline \multirow[t]{2}{*}{3} & $\begin{array}{l}\text { Aja- } \\
\text { kirjandus }\end{array}$ & 1,1 & 3,8 & 3,6 & 0,9 & 1,2 & 1,4 & 12,1 \\
\hline & Teadus & 0 & 2,6 & 1,6 & 0,1 & 0,5 & 1,2 & 6,0 \\
\hline \multicolumn{2}{|r|}{ Kokku } & 83,9 & 23,7 & 54,1 & 6,1 & 10,4 & 5,5 & 187,9 \\
\hline
\end{tabular}




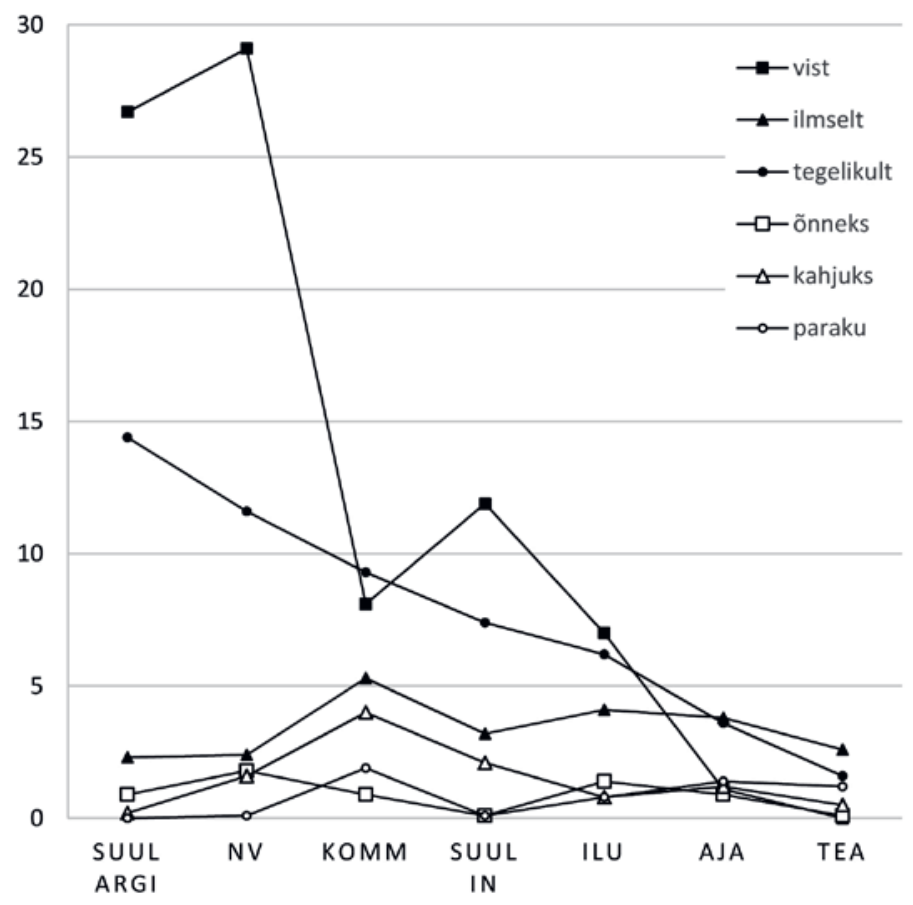

Joonis. Partiklite kasutussagedus registrites

Tabel 3 näitab, et partiklite üldise kasutussageduse alusel jagunevad registrid kolme rühma. Esimese rühma moodustavad argi- ja netivestlus, teise institutsionaalne suhtlus, netikommentaarid ja ilukirjandus ning kolmanda ajakirjandus ja teadus. Samas on näha, et selliste rühmade moodustumise määrab suurima ning registriti kõige varieeruvama sagedusega partikkel vist. Ülejäänud partiklite alusel moodustuvad kas teistsugused rühmad või kontiinum, milles selgeid rühmadevahelisi piire ei ole. Näiteks väheneb partikli tegelikult sagedus sujuvalt 14,4-st argivestlustes kuni 1,6-ni teadustekstides ning partikli õnneks sageduse alusel eristuvad teistest registritest institutsionaalne suhtlus ja teadus, kus selle partikli sagedus on nullilähedane.

Teine võimalus registreid rühmadesse koondada on lähedase tähendusega partiklite kasutussageduse suhte alusel. Partiklite vist ja ilmselt suhe annab peaaegu samasugused rühmad nagu partiklite kogusagedus. Vist on üle kümne korra sagedasem kui ilmselt argi- ja netivestlustes, ligi 
neli korda sagedasem institutsionaalses suhtluses, umbes poolteist korda sagedasem ilukirjanduses ja netikommentaarides. Ilmselt on sagedasem kui vist ajakirjanduses ja teaduses. ${ }^{8}$ Partiklite kahjuks ja paraku suhte põhjal eristuvad teadustekstid, milles paraku on sagedasem kui kahjuks, ning argivestlused, institutsionaalne suhtlus, netivestlused ja netikommentaarid, milles kahjuks on sagedasem kui paraku. (Vt joonis.)

Statistiline ülevaade näitab, et partiklite kasutust tuleb vaadata ükshaaval. Järgmises osas selgitame, milliste konsituatiivsete teguritega seostuvad partiklite kasutussagedused.

\section{Konsituatiivsed tegurid ja partiklite kasutussagedus}

Selles jaotises vaatame, milliste kontekstuaalsete teguritega seostuvad eri partiklite kasutussagedused (tabel 3). Seletamiseks kasutame varasemates uurimustes välja toodud konsituatiivseid tegureid (tabel 1) ning lisame neile uusi (tabel 4).

\subsection{Episteemilised partiklid}

Esimese partiklirühma moodustavad episteemilised partiklid vist, ilmselt ja tegelikult.

Partikli vist kasutus jaguneb sageduse järgi kolmeks rühmaks. Vist esineb väga sageli argi- ja netivestluses, mida iseloomustavad dialoogilisus, spontaansus, kaasatus ja argisus. Spontaanne vestlus kasutab palju eri pehmendajaid, mis väljendavad ebakindlust öeldu tõeväärtuse suhtes (nt Biber, Conrad 2009: 236-241; Hennoste jt 2020). Selle taustaks on vajadus reageerida kiiresti partneri jutule, mis ei võimalda alati leida täpset väljendust. Olulisim mõju suulise keelevariandi sees paistab olevat spontaansusel, tugeval kaasatusel ja argisusel. Seda näitab asjaolu, et institutsionaalses suhtluses, mis on argivestlusest vähem spontaanne ja rohkem infole orienteeritud, on ka partikli vist sagedus väiksem. Institutsionaalne suhtlus soosib info suuremat täpsust.

Partiklit vist esineb vähe ajakirjanduses ja eriti teaduses. Neile registritele on omased tekstide monoloogilisus, redigeeritus, infokesksus,

${ }^{8}$ Samalaadseid tendentse täheldavad ka Luik (2020: 20-21) ja Virroja (2020: 35): ajakirjandustekstide ja televisiooni poliitikasaate materjalis leidus suurema tõenäosuse markereid väiksema tõenäosuse markeritest rohkem. 
vahendatus ja ametlikkus. Teistest registritest eristab seda rühma tekstide seletav loomus, mis on valdav teaduses ja tähtis ka ajakirjanduses. Samuti on siin mõju partikli vist tähendusel. Ajakirjandust ja teadust iseloomustab tõsikindluse taotlus, millega ebakindlusele viitav vist semantiliselt ei sobi.

Statistiliselt vahepealse rühma moodustavad institutsionaalne suhtlus, netikommentaarid ja ilukirjandus. Siin on näha, et institutsionaalses suhtluses esineb vist sagedamini kui kommentaarides ja kirjanduses. Seda eristavad kommentaaridest ja kirjandusest suulisus, dialoogilisus ja suurem spontaansus. Samad tegurid on tähtsad kommentaarides, mis kuuluvad avaliku suhtluse alla, kus reageeritakse üldjuhul kiiresti ja spontaanselt, kuid siiski aeglasemalt kui suuliselt suheldes. Samuti on siin tähtis, et kommentaaritekstid esitavad kirjutaja personaalseid seisukohti. Eraldi küsimuse tekitab aga ilukirjanduse paigutumine. Kuigi ilukirjanduses on partikli vist sagedus väiksem kui institutsionaalses suhtluses ja netikommentaarides, kuulub ta siiski kokku nende ja mitte ajakirjanduse ega teadusega. Ilukirjandus erineb viimastest kolmes suhtes: see on jutustav, pigem kaasav ning avalik tekst. Lisaks iseloomustab seda kolm tegurit, mida varasemates uurimustes pole mainitud.

Esiteks, nagu teised kirjalikud tekstid, nii on ka ilukirjandus loomult monoloogiline, samas väljenduse tasandil eristavad seda monoloogi (autorikõne) ja dialoogi (tegelaskõne) koosesinemine ja vaheldumine. Sealjuures ei ole tegu mitte spontaanse, vaid kirjaniku konstrueeritud dialoogiga, mille ülesanne on viia sündmustikku edasi ja/või iseloomustada tegelasi. Kirjanduslik dialoog on suulise dialoogi tihendatud ja korrastatud variant, mis samal ajal imiteerib tihti spontaansust ja suulisust, et luua kõne illusiooni (Leech, Short 2007: 129-134). ${ }^{9}$ See näitab, et partikli vist sagedust mõjutab ka konstrueeritud-imiteeriv dialoog ${ }^{10}$ ning järelikult tuleb analüüsis eristada dialoogilisust kui teksti loomise ja suhtlemise

9 Jätame siinkohal kõrvale kirjandusdialoogi keerulised suhted nt kirjandusvooludega (vt ülevaatlikult nt Nykänen, Koivisto 2013: 9-56).

${ }^{10}$ Konstrueeritud-imiteeriva dialoogi näitena olgu siinkohal lausele (4) lisatud selle lähem kontekst.

„Sa oled kah ... Mina sinust aru ei saa.“

„Ma ise ei saa ka mõnikord. Aga see tibi, kes siin elas, sul jäi mingi jutt pooleli vist.“ „Nojah. Läks, kuhu läks, nüüd olen ma siin üksi, vahepeal mõtlesin, et leiaks mingi kuti, laseks tal üüri maksta. Aga - ise tead, kuidas nende kuttidega on.“" (ILU) 
viisi ning dialoogi kui loomult monoloogilise teksti vormistamise viisi.

Teiseks, erinevalt teadusest ja ajakirjandusest ei tegele ilukirjandus tõsikindlust eeldava info vahendamisega ning seetõttu võib ta kasutada rohkem ebakindlusele viitavaid markereid.

Kolmandaks, ilukirjandust eristab teistest trükitekstidest ka toimetamise eripära. Toimetatus iseloomustab, millised on ühiskonnas mingile tekstiliigile kehtivad toimetamisnormid ja/või -tavad ning mil määral toimetaja neist lähtub. Kirjanduses on oluline licentia poetica, mis lubab autorile suuri vabadusi ning kitsendab toimetaja volitusi ja võimalusi. Teaduses ja ajakirjanduses on olemas kindlad toimetamisnormid, mida toimetaja üldjuhul järgib (nt üldised teaduskirjutuse normid või lehetoimetustes kehtestatud normid). Kuna need tekstirühmad peaks pakkuma tõsikindlat infot, võib siin suure tõenäosusega oletada, et osalt on toimetajad ebakindlusele viitava partikli vist nendest tekstidest välja redigeerinud. Seega võime üldistada, et need kaks tekstirühma ei vaja seda partiklit, väldivad seda või on see neist välja toimetatud.

Kokkuvõttes on partikli vist sagedused suuremas osas seletatavad teguritega, mida on ka varem partiklite sageduse seletamisel nimetatud. Lisaks tõime sisse tegurid, mida varem pole arvestatud: konstrueeritud, suulist keelt imiteeriv dialoogi kasutus, toimetamisnormid, tekstide seos üldise n-ö objektiivse tõe vahendamisega.

Ilmselt on analoogiline partikliga vist, olles tõlgendatav selle sünonüümina. Samas ei ole tegu absoluutse sünonüümiga. Ilmselt märgib öeldu suuremat tõenäosust kui vist ning teisalt viitab asjaolule, et öeldu on silmanähtav ja kuidagi põhjendatud. Statistika näitab, et partikli ilmselt sagedus varieerub valdavalt teisiti kui partiklil vist, selle kasutussagedus on üldiselt väike ning ka erinevused registrite vahel suhteliselt vähesed.

Esiteks, partikli ilmselt vähene esinemine teaduses on seletatav tema semantilise ebasobivusega, nagu ka partikli vist puhul. Samas esineb ta teadustekstides sagedamini kui vist. See on kooskõlas partikli ilmselt tähenduses väljenduva suurema tõenäosuse ja põhjendatusega. Samuti võib välja pakkuda, et uue ja kirjakeelse sõnana mõjub ilmselt stiililt ametlikumana kui vist ning sobib sellisena paremini ka teadusteksti toimetamise normidega.

Teisalt paistab silma, et nii suulises kui ka netivestluses esineb ilmselt sama sagedusega kui teaduses, samal ajal kui vist oli vestlustes väga sage. 
Selle seletamiseks pakume, et spontaanses argivestluses täidab partikkel vist võimalusel ja vajadusel ka partikli ilmselt kohta. Spontaanses suhtluses valitsevad kordused ning kehtib ökonoomiapõhimõte, mis soosib paljudesse kontekstidesse sobivaid üksusi, millega saab täita eri funktsioone (vt nt Rühlemann 2007). Selleks sobib laia kasutusvaldkonnaga partikkel vist. Samuti ei ole argivestluses oluline osutada öeldu silmanähtavusele ja põhjendatusele, seega pole ka vajadust partikli ilmselt eritähenduse järele.

Kolmandaks on näha, et ilmselt esineb netikommentaarides, institutsionaalses suhtluses, ilu- ja ajakirjanduses sagedamini kui argistes registrites. ${ }^{11}$ Meie arvates on siin tegu ennekõike kahe sõna stiilierinevuste mõjuga. Ilmselt on uuem, ametlikum, kirjakeelsem partikkel kui vist. $\mathrm{Nt}$ 19. sajandi algupoolel (O. W. Masingul) on see kasutusel veel viisimäärsõnalises tähenduses 'silmanähtavalt' ning puudub partiklina 1925. a „Eesti õigekeelsuse-sõnaraamatus“. Annika Küngase andmetel (2014: 13) on selle kasutus kirjakeeles saja aasta jooksul sujuvalt suurenenud. Samuti võib siin üldise tendentsina viidata avalike-ametlike registrite tugevamale tõe ja täpsuse poole suunatusele.

Neljandaks, partikli ilmselt küllalt suur sagedus ilu- ja ajakirjanduses on seletatav toimetamisnormidega, kuid siin tuleb pigem esile norm, mis soosib neis registrites kordamise asemel potentsiaalsete sünonüümide vaheldamist.

Seega näeme, et partikli ilmselt sagedusi saab lisaks partikli semantikale seletada tõesuse rõhutamise, stiili ja toimetamisnormidega. Uue tegurina pakume siin välja nii spontaansusega kui ka toimetamisnormiga seostuva korduvuse $v s$. vaheldumise eelistuse.

Partikli vist kõrval on teine märgatavalt varieeruva sagedusega partikkel tegelikult, mille sageduse varieerumine on sujuv, kuid siiski põhiliselt analoogiline partikli vist omaga. Samas on see partikkel oma tähenduselt ja kasutuselt teistsugune. Tegelikult väljendab oma funktsionaalses tuumas tõsikindlust, mis vastandub partikli vist ebakindlusele ning on lisaks kasutusel pehmendajana tähenduses 'õigupoolest, tõtt-öelda, õieti'. Olulisim on aga mõlemat kasutust ühendav esinemine valdavalt vastanduvas kontekstis. Selline vastandus eeldab teist seisukohta, mida võib esitada

${ }^{11}$ Seda kinnitab ka suulise keele korpuse üldine statistika. Partikkel vist esineb enam argisuhtluses (827 vs. 421 kasutust) ja ilmselt ametisuhtluses (132 vs. 76). 
dialoogipartner, aga mis võib olla ka tekstis implitsiitne, viidates suhtlejate ühisele teadmisele. ${ }^{12}$

Partikli tegelikult vastandava kasutusega on kooskõlas tema suurem sagedus dialoogides või dialooge sisaldavates registrites (suulised ja netivestlused, institutsionaalne suhtlus, netikommentaarid ja ilukirjandus). Nende rühmade sees esineb tegelikult kõige sagedamini argi- ja netivestlustes ja kommentaarides ning vähem institutsionaalses suhtluses ja ilukirjanduses. Siin on tähtis, et argine suhtlusolukord võimaldab üldiselt enam ja teravamat vastandumist kui viisakust rõhutav institutsionaalne suhtlus ning kommentaarides on oma tõe kuulutamine ja vastandumine väga tavalised tegevused. Kokkuvõttes saame siin uue seletava tegurina sisse tuua vastanduse vältimise või mittevältimise.

\subsection{Hinnangu-hoiakupartiklid}

Järgnevalt vaatame hinnangu-hoiakupartikleid õnneks, kahjuks ja paraku. Hoiakupartikleid kokku esineb eriti palju netikommentaarides, rohkesti netivestluses, ajakirjanduses, ilukirjanduses, keskmiselt institutsionaalses suhtluses, vähe aga teaduses ja argivestluses. Eriti vähe esineb hoiakupartikleid argivestluses, mis erineb muudest registritest ka partiklite valiku poolest. Siin prevaleerib ainsana partikkel õnneks. Samas võiks just argivestluses eeldada laiemat kõneleja hoiakute väljendamist. Siin võib pakkuda mitut seletust.

Hoiakupartiklite kasutamine eeldab selle nähtuse tõesust, mille kohta hoiakut väljendatakse. Sellisena on eeldatav, et neid on vähe tekstides, kus tõesuse eele on ebaoluline või halvasti täidetav. Argivestlus ongi selline register, mida näitas ka partikli vist väga sage esinemine. Samas on argivestluses hoiakupartikleid palju vähem kui vähehoiakulises institutsionaalses suhtluses. Siin on üks võimalik seletus peidus uuritavas materjalis. Meie kasutatud institutsionaalse suhtluse korpus esindab valdavalt telefonisuhtlust, argivestlus aga enam silmast silma suhtlust. Sellisena on argivestluses võimalik kasutada partiklite asemel mitteverbaalseid

${ }^{12}$ Vastandavat funktsiooni on nimetanud ka Annika Valdmets (2013: 121-124), kes lähtub üksuse tegelikult kasutusfunktsioonide kirjeldamisel siinsest erinevast terminoloogiast, eristades sõna tegelikult viisiadverbilist, modaalpartiklilist (tõenäosuspartikli) ja diskursusemarkeri funktsiooni kui eri astmeid grammatiseerumise ahelas. 
hoiakumarkereid, nt žeste ja näoliigutusi. Teisalt on institutsionaalses suhtluses partiklite õnneks ja kahjuks/paraku suhe argivestlusega võrreldes vastupidine. Suurem partiklite kahjuks/paraku kasutus võib siin viidata viisakusele, vajadusele pehmendada vastandumist, mitte-eelistatud seisukohta, fakti jm mitte-eelistatud infot (kahjuks seda kaupa ei ole jms).

Netivestluse puhul näeme, et seal esineb hoiakupartikleid palju rohkem kui argivestluses, mis on sellega oma tõesuse-eelete poolest analoogiline. Ka siin võib olla üheks seletuseks mitteverbaalsete markerite kasutamise võimatus, kuigi sellele paistab vastu rääkivat asjaolu, et netivestluses kasutatakse palju emotikone. Siiski ei ole siin vasturääkivust, sest emotikone kasutatakse ainult osalt hoiakute väljendamiseks, nende niisama oluline (kui mitte olulisem) roll on lisada kirjutatule üldist emotsionaalset värvingut. Samas on näha, et netivestluses on hoiakumarkereid vähem kui netikommentaarides. Siin võib pakkuda seletuseks kommentaaride suuremat hoiakulisust, lisaks paistab tekstidest välja, et netikommentaarides on kahjuks sageli iroonia vahend. Trükitekstidest esineb hoiakupartikleid vähe teaduses, mis on kooskõlas selle tekstiliigi hoiakuid vältiva loomusega. Sealjuures valitseb ka seal teadusteksti paremini sobiv kahjuks/paraku, mis viitab info mitteootuspärasusele.

Palju esineb hoiakupartikleid ilukirjanduses ja ajakirjanduses. Kirjandus on hoiakuline register ning esindab $\mathrm{mh}$ tegelaste vestluste imitatsioone, kus hoiakupartiklite suur sagedus on ootuspärane. Sealjuures on trükitekstis vähe võimalusi asendada partikleid žestide ja miimika kirjeldamisega. Võib arvata, et ajakirjanduses väljendatakse hoiakuid lugejate tähelepanu tõmbamiseks.

Partiklite kahjuks ja paraku erinevus avaldub selles, et kahjuks esineb palju sagedamini netivestluses, institutsionaalses suhtluses ja netikommentaarides. Muudes registrites on partiklid kasutusel suhteliselt võrdselt. Need kaks rühma erinevad kõigepealt selle poolest, et esimeses eelistatakse kordamist ja teises sünonüümide kasutust. Teisalt paistab silma lahknevus toimetatud trükitekstide ja toimetamata tekstide vahel. Siin võib erinevuse põhjusena oletada toimetamisnormi, mis soosib sünonüümide vaheldamist. Samuti on oma osa stiilivahel: sagedasem on just tavaline emotsionaalset suhtumist väljendav kahjuks ja harvem stiililt markeeritud, osaliselt möönvuse säilitanud paraku.

Kokkuvõttes on hoiakupartiklite sageduste seletamine keerukas ja ebakindel. Oletada võib, et nende sagedusi mõjutab põimuv tegurite kogum, 
mille sees on olulised teksti seos tõe väljendamisega, vajadus pehmendada mitte-eelistatud infot, võimalus või võimatus kasutada mitteverbaalseid hoiakuvahendeid, stiililine markeeritus, vaheldamise vajadus. Lisaks on usutav, et mõnel juhul on partiklite sagedus seotud ka analüüsivalimisse sattunud konkreetsete tekstide teemadega.

\subsection{Vahekokkuvõte}

Kokkuvõttes saame öelda, et varasemates uurimustes nimetatud konsituatiivsed tegurid seletavad suuremal määral ainult partikli vist kasutust. Neile lisaks tuleb sisse tuua uusi seletavaid tegureid (tabel 4):

- teksti seos tõega ja vajadus tõesust rõhutada (vist, ilmselt, hoiakupartiklid);

- dialoogi kasutus tekstis ja spontaanset suhtlust imiteeriv konstrueeritud dialoog (vist);

- toimetamisnormid ja licentia poetica (vist, ilmselt, hoiakupartiklid);

- korduvuse $v s$. vaheldamise eelistamine (ilmselt, hoiakupartiklid);

- vastandumise ja mitte-eelistatud info kasutus (tegelikult, hoiakupartiklid);

- mitteverbaalsete vahendite kasutamise võimalus (hoiakupartiklid).

Tabel 4. Uurimuse käigus lisandunud konsituatiivsed tegurid

\begin{tabular}{|l|c|c|c|c|c|c|c|}
\hline Registrid & $\begin{array}{c}\text { Seos } \\
\text { tõega: } \\
\text { oluline / } \\
\text { ei ole }\end{array}$ & $\begin{array}{c}\text { Dialoogi } \\
\text { kasutus }\end{array}$ & $\begin{array}{c}\text { Suulise } \\
\text { dialoogi } \\
\text { imitat- } \\
\text { sioon }\end{array}$ & $\begin{array}{c}\text { Toimeta- } \\
\text { misnor- } \\
\text { mid }\end{array}$ & $\begin{array}{c}\text { Kor- } \\
\text { duvus/ } \\
\text { vahel- } \\
\text { dus }\end{array}$ & $\begin{array}{c}\text { Vas- } \\
\text { tandu- } \\
\text { mine }\end{array}$ & $\begin{array}{c}\text { Mitte- } \\
\text { ver- } \\
\text { baalne }\end{array}$ \\
\hline Argivestlus & ei & ei & ei & ei & K & jah & jah \\
\hline Netivestlus & ei & ei & ei & ei & K & jah & jah \\
\hline $\begin{array}{l}\text { Institut- } \\
\text { sionaalne } \\
\text { suhtlus }\end{array}$ & jah & ei & ei & ei & $\mathrm{K}$ & ei & (jah) \\
\hline $\begin{array}{l}\text { Neti- } \\
\text { kommentaar }\end{array}$ & ei & ei & (jah) & ei & $?$ & jah & ei \\
\hline $\begin{array}{l}\text { Ilukirjandus- } \\
\text { lik proosa }\end{array}$ & ei & jah & jah & (jah) & V & $?$ & ei \\
\hline Ajakirjandus & jah & (jah) & ei & jah & V & ei & ei \\
\hline Teadus & jah & ei & ei & jah & $?$ & jah & ei \\
\hline
\end{tabular}


Samuti mängib mõnel juhul rolli konkreetse partikli tähendus ning stiililine neutraalsus või markeeritus (vist vs. ilmselt, kahjuks vs. paraku), konkreetse tekstiliigi eripära (netikommentaarid) ja teemad ning ka analüüsitava korpuse loomus (silmast silma $v s$. telefonisuhtlus).

\section{Kokkuvõte}

Artiklis analüüsisime episteemiliste partiklite vist, ilmselt ja tegelikult ning hinnangu-hoiakupartiklite õnneks, kahjuks ja paraku kasutust suulises argivestluses, institutsionaalses suhtluses, ilukirjanduslikus proosas, ajakirjanduses, teaduses, netivestlustes ja netikommentaarides.

Esmalt vaatasime partiklite tähendusi, eripäraseid kontekste ja positsioone lausungis. Siin on oluline välja tuua kaks asjaolu. Esiteks, partiklite kasutuskontekstid on osalt erinevad. Partiklit vist esineb teistest palju enam küsimustes ja vastustes, tegelikult, kahjuks ja paraku tulevad esile ennekõike vastandavates kontekstides. Teiseks, kõik partiklid esinevad lausungi kõigis positsioonides, sealjuures väga valdavalt oma mõjuala ees, harva selle järel. Asendi poolest on oluline erinevus episteemiliste ja hoiakupartiklite vahel. Episteemilised partiklid esinevad valdavalt lausungi sees oma mõjuala ees. Sealjuures on see partikli vist jaoks põhiline positsioon, ilmselt ja tegelikult paiknevad nii lausungi absoluutses alguses kui ka lausungi sees teise osalause alguses palju sagedamini. Õnneks, kahjuks ja paraku esinevad lausungi sees ja alguses suhteliselt võrdselt ning muudes positsioonides harva. Selle kaudu paistab välja ka kahe partiklirühma mõjualade erinevus. Episteemiliste partiklite mõjualaks on ennekõike neile järgnev lausungiosa, hoiakupartiklitel keskset mõjuala ei ole. Samas siinsel analüüsitasemel partiklite positsioonide ning nende sageduste ja konsituatiivsete tegurite vahel otseseoseid välja ei tule.

Teiseks vaatasime partiklite kasutussagedust eri registrites. Tulemused näitasid, et partikleid koos vaadates kinnitab eesti keel teistes keeltes leitud statistilist jaotust (tabel 3). Partikleid kasutatakse eriti palju argi- ja netivestlustes ehk argiregistrites ning eriti vähe ajakirjanduses ja teaduses. Institutsionaalne suhtlus, netikommentaarid ja ilukirjandus jäävad nende vahele. Samas tõi analüüs esile, et sellise tulemuse tekitab ennekõike sagedasim partikkel vist ning ainult vist ja tegelikult sobivad üldisesse statistilisse mustrisse. Ülejäänud partiklid käituvad erinevalt. Kesksena tõusis esile asjaolu, et partiklite vähene kasutus teadus- ja ajakirjandustekstides 
on üldise tendentsiga kooskõlas, samal ajal ei sobi sellega kokku partiklite vähesus ja hüplik sageduste varieerumine ilukirjanduses, netitekstides ja suulises kõnes. See näitas, et partikleid tuleb analüüsida ükshaaval, registriuuringutes üldiselt kasutatav partiklite koosvaatlus annab osalt väära pildi.

Kolmandaks vaatasime konsituatiivseid tegureid, millega partiklite kasutussagedusi on seletatud (tabelid 1 ja 4). Siin võimaldab analüüs teha kaks üldistavat järeldust. Esiteks, varem väljatoodud seletavatest teguritest ei piisa. Ainult partikli vist sagedused on nende abil suuremas osas seletatavad, kuid ka siin tuleb lisada uusi. Ülejäänud partiklite puhul sobivad seni toodud tegurid veel vähem. Sealjuures ei toimi need tegurid kõigis registrites korraga või samal viisil.

Partikli vist sageduse varieerumise seletuseks sobivad tegurid on suulisus, dialoogilisus/monoloogilisus, spontaansus/redigeeritus, kaasatus/ infokesksus, argisus/avalikkus/ametlikkus, vahendatus, jutustavus/ seletavus, lisaks sõna semantika. Uute teguritena tõime sisse tõesuse eelde, spontaansust imiteeriva konstrueeritud dialoogi ilukirjanduses ning toimetamisnormid, mis tulevad erinevalt esile ilukirjanduses ning teaduses ja ajakirjanduses.

Analüüs näitas, et ilmselt on mõnel juhul partikli vist sünonüüm, kuid selle kasutus varieerub enamjaolt partikli vist kasutusest erinevalt. Semantika põhjendab partikli vist kasutusest suuremat sagedust teadustekstides. Uute teguritena lisandusid stiililine markeeritus ja korduvuse või vaheldumise eelistus. Ühelt poolt eristuvad stiililt neutraalne ja kõikidesse registritesse sobiv vist ning ametlikuma stiiliga seostuv ilmselt. Teisalt eristuvad registrid, mis eelistavad (või taluvad) partikli kordamist ja ökonoomiat, ning registrid, mis eelistavad partiklite vaheldumist. Ka see tegur seostub laias mõttes stiiliga.

Partikli tegelikult sageduse varieerumise põhiliseks jooneks peame esinemist vastanduvates kontekstides. Seejuures tuleb arvestada asjaolu, kas vastavas registris eelistatakse vastanduse vältimist või ei ole see oluline. Laiemalt on siin selge erinevus argiste ja mitteargiste registrite vahel, argiregistrites on eksplitsiitse vastanduse talutavuse määr kõrgem.

Hoiakupartiklite seletamine osutus keerukaks ja jääb mitmes punktis hüpoteeside tasandile. Siin pakkusime välja valdavalt samad tegurid, mis seletasid muid partikleid: teksti seos tõega, hoiakute väljendamine või vältimine, vajadus pehmendada mitte-eelistatud infot, korduvuse vs. vaheldamise eelistus ja nendega seotud toimetamisnormid, partikli 
stiililine markeeritus. Lisaks tõime tegurina sisse võimaluse kasutada mitteverbaalseid hoiakuvahendeid, mis on oluline suulises argiregistris ja praegusel juhul ilmselt seotud siinse tekstikorpuse olemusega.

Üldistavalt saab analüüsi põhjal tuua esile neli metodoloogilist asjaolu.

Esiteks, (inter)subjektiivsuse analüüsis tüüpiline piirdumine suulise ja kirjaliku keelekasutuse võrdlusega on liiga üldine. Partiklite sagedusega seostuvad paljud erinevad konsituatiivsed tegurid.

Teiseks, registrianalüüsis tavaline lähenemine, milles käsitletakse erinevaid episteemilisi või hoiakupartikleid rühmana, ei ole sobiv. Eri partiklid käituvad erinevalt ning neid tuleb analüüsida ükshaaval. Alles selle järel on võimalik välja selgitada, kas leidub sarnaselt käituvaid partikleid ja millised need on.

Kolmandaks, partiklite sageduse varieerumise seletamiseks pakutud konsituatiivsed tegurid toimivad kindlates piirides. Nad sobivad ainult osa partiklite sageduse varieerumise seletamiseks ega seleta kõiki muutusi. Seega on vaja lisada uusi tegureid või liigendada praegused tegurid kitsamaks.

Neljandaks, mõne partikli sageduse varieerumine võib siiski olla eraldi võttes väga hea kriteerium registrite eristamiseks. Selleks sobivad ennekõike neutraalsed ja laia kasutusega partiklid, nagu ebakindla teadmise väljendaja vist ning vastandusele viitav partikkel tegelikult. Ebakindlus ja vastandus on suhtluses universaalsed nähtused, mis võimaldavad tuua esile erinevuse normist, milleks on kindel teadmine ning vastanduse puudumine.

\section{Lühendid}

AJA - ajakirjandus; ILU - ilukirjanduslik proosa; KOMM - netikommentaarid; NV - netivestlused; SUUL IN - institutsionaalne suhtlus; SUUL ARGI - suuline argivestlus; TEA - teadus

\section{Kirjandus}

Aijmer, Karin 2013. Understanding Pragmatic Markers: A Variational Pragmatic Approach. Edinburgh: Edinburgh University Press.

Baron, Naomi S. 2008. Always On: Language in an Online and Mobile World. New York: Oxford University Press. http://dx.doi.org/10.1093/acprof: oso/9780195313055.001.0001

Baron, Naomi S. 2013. Instant messaging. - Pragmatics of Computer-Mediated Communication. Ed. by Susan S. Herring, Dieter Stein, Tuija Virtanen. 
(= Handbooks of Pragmatics 9.) Berlin, Boston: De Gruyter Mouton, 135-161. https://doi.org/10.1515/9783110214468.135

Biber, Douglas 1988. Variation across Speech and Writing. New York: Cambridge University Press. https://doi.org/10.1017/CBO9780511621024

Biber, Douglas 1995. Dimensions of Register Variation: A Cross-Linguistic Comparison. Cambridge: Cambridge University Press. https://doi. org/10.1017/CBO9780511519871

Biber, Douglas, Susan Conrad 2009. Register, Genre, and Style. (= Cambridge Textbooks in Linguistics.) Cambridge: Cambridge University Press. https://doi.org/10.1017/CBO9780511814358

Breitkopf-Siepmann, Anna 2012. Hedging in German and Russian conference presentations: A cross-cultural view. - Subjectivity in Language and Discourse. Ed. by Nicole Baumgarten, Inke Du Bois, Juliane House. (= Studies in Pragmatics 10.) Leiden: Brill, 295-318. https://doi. org/10.1163/9789004261921_014

Chafe, Wallace L. 1982. Integration and involvement in speaking, writing, and oral literature. - Spoken and Written Language: Exploring Orality and Literacy. Ed. Deborah Tannen. Norwood: Ablex, 35-53.

Chafe, Wallace L., Jane Danielewicz 1987. Properties of spoken and written language. - Comprehending Oral and Written Language. Ed. by Rosalind Horowitz, S. Jay Samuels. Academic Press, 83-113.

Crystal, David 2006. Language and the Internet (2. ed.). Cambridge: Cambridge University Press. https://doi.org/10.1017/CBO9780511487002

Degand, Liesbeth, Anne-Marie Simon-Vandenbergen (eds.) 2011. Grammaticalization, pragmaticalization and (inter)subjectification: Methodological issues in the study of discourse markers. - Linguistics 49 (2).

EKG II = Mati Erelt, Reet Kasik, Helle Metslang, Henno Rajandi, Kristiina Ross, Henn Saari, Kaja Tael, Silvi Vare 1993. Eesti keele grammatika. II. Süntaks. Lisa: Kiri. Trükki toimetanud Mati Erelt (peatoimetajana), Tiiu Erelt, Henn Saari, Ülle Viks. Tallinn: Eesti Teaduste Akadeemia Keele ja Kirjanduse Instituut.

Fanego, Teresa 2010. Paths in the development of elaborative discourse markers: Evidence from Spanish. - Subjectification, Intersubjectification and Grammaticalization. Ed. by Kristin Davidse, Lieven Vandelanotte, Hubert Cuyckens. Berlin, New York: De Gruyter Mouton, 197-240. https://doi. org/10.1515/9783110226102.2.197

Fitzmaurice, Susan 2004. Subjectivity, intersubjectivity and the historical construction of interlocutor stance: From stance markers to discourse markers. - Discourse Studies 6 (4), 427-448. https://doi. org/10.1177\%2F1461445604046585

Haselow, Alexander 2012. Subjectivity, intersubjectivity and the negotiation of common ground in spoken discourse: Final particles in English. - 
Language \& Communication 32 (3), 182-204. https://doi.org/10.1016/j. langcom.2012.04.008

Hennoste, Tiit 2000. Allkeeled. - Eesti keele allkeeled. Toim. Tiit Hennoste. (= Tartu Ülikooli eesti keele õppetooli toimetised 16.) Tartu: Tartu Ülikool, 9-56.

Hennoste, Tiit 2008. Uudise käsiraamat. Kuidas otsida, kirjutada, toimetada ja serveerida ajaleheuudist. 2. kohendatud trükk. Tartu: Tartu Ülikooli Kirjastus.

Hennoste, Tiit, Olga Gerassimenko, Riina Kasterpalu, Mare Koit, Kirsi Laanesoo, Anni Oja, Andriela Rääbis, Krista Strandson 2010. The structure of a discontinuous dialogue formed by internet comments. Text, Speech and Dialogue. Ed. by Petr Sojka, Aleš Horák, Ivan Kopeček, Karel Pala. Berlin, Heidelberg: Springer-Verlag, 515-522.

Hennoste, Tiit, Külli Habicht, Helle Metslang, Külli Prillop, Kirsi Laanesoo, David Ogren, Liina Pärismaa, Elen Pärt, Andra Rumm, Andriela Rääbis, Carl Eric Simmul 2020. Diskursusemarker (ma) arvan (et). Emakeele Seltsi aastaraamat 65. Peatoim. Mati Erelt. Emakeele Selts. Tallinn: EKSA, 63-90. http://dx.doi.org/10.3176/esa65.03

Hennoste, Tiit, Helle Metslang, Külli Habicht, Anni Jürine, Kirsi Laanesoo, David Ogren 2016. Üldküsimuse vorm ja funktsioonid läbi nelja sajandi ja kuue tekstiliigi. - Emakeele Seltsi aastaraamat 61. Peatoim. Mati Erelt. Emakeele Selts. Tallinn: Teaduste Akadeemia Kirjastus, 80-109. http:// dx.doi.org/10.3176/esa61.04

Hennoste, Tiit, Karl Pajusalu 2013. Eesti keele allkeeled. Õpik gümnaasiumile. Tallinn: Eesti Keele Sihtasutus.

Herring, Susan C., Dieter Stein, Tuija Virtanen (eds.) 2013. Pragmatics of Computer-Mediated Communication. (= Handbooks of Pragmatics 9.) Berlin, Boston: De Gruyter Mouton. https://doi.org/10. 1515/9783110214468

House, Juliane 2013. Developing pragmatic competence in English as a lingua franca: Using discourse markers to express (inter)subjectivity and connectivity. - Journal of Pragmatics 59, Part A, 57-67. http://dx.doi. org/10.1016/j.pragma.2013.03.001

Jonsson, Ewa 2015. Conversational Writing: A Multidimensional Study of Synchronous and Supersynchronous Computer-Mediated Communication. Peter Lang Edition. https://doi.org/10.3726/978-3-653-06512-1

Kaalep, Heiki-Jaan, Kadri Muischnek 2002. Eesti kirjakeele sagedussõnastik. Tartu: Tartu Ülikooli Kirjastus.

Kehayov, Petar 2009. Interaction between grammatical evidentials and lexical markers of epistemicity and evidentiality: A case study of Bulgarian and Estonian. - Wiener Slawistischer Almanach 72, 165-201. 
Küngas, Annika 2014. Pragmaatiliste markerite kujunemine ja funktsioonid eesti keeles $l t$-sõnade näitel. (= Dissertationes philologiae estonicae universitatis Tartuensis 36.) Tartu: Tartu Ülikooli Kirjastus.

Leech, Geoffrey, Mick Short 2007. Style in Fiction: A Linguistic Introduction to English Fictional Prose. 2nd ed. London: Longman.

Luik, Alice 2020. Episteemilise modaalsuse markerite kasutusfunktsioonidest eesti keeles. Bakalaureusetöö. Tallinn: Tallinna Ülikool.

Marin-Arrese, Juana I. 2007. Commitment and subjectivity in the discourse of opinion columns and leading articles. A corpus study. - RAEL: revista electrónica de lingüística aplicada, Extra 1, 82-98.

Mortensen, Janus 2012. Subjectivity and intersubjectivity as aspects of epistemic stance marking. - Subjectivity in Language and Discourse. Ed. by Nicole Baumgarten, Inke Du Bois, Juliane House. (= Studies in Pragmatics 10.) Leiden: Brill, 229-246. http://dx.doi.org/10.1163/9789004261921 011

Narrog, Heiko 2017. Three types of subjectivity, three types of intersubjectivity, their dynamicization and a synthesis. - Aspects of Grammaticalization: (Inter)subjectification and Directionality. Ed. by Daniël Van Olmen, Hubert Cuyckens, Lobke Ghesquière. Berlin, Boston: De Gruyter Mouton, 19-46. https://doi.org/10.1515/9783110492347-002

Nuyts, Jan 2012. Notions of (inter)subjectivity. - English Text Construction 5 (1), 53-76. https://doi.org/10.1075/etc.5.1.04nuy

Nykänen, Elise, Aino Koivisto 2013. Näkökulmia kaunokirjalliseen dialogiin. Dialogi kaunokirjallisuudessa. Toim. Aino Koivisto, Elise Nykänen. (= Tietolipas 242.) Helsinki: Suomen Kirjallisuuden Seura, 9-56.

Pho, Phuong Dzung 2012. Authorial stance in research article abstracts and introductions from two disciplines. - Subjectivity in Language and Discourse. Ed. by Nicole Baumgarten, Inke Du Bois, Juliane House. Leiden: Brill, 97-114. http://dx.doi.org/10.1163/9789004261921_006

Piórkowska, Agnieszka 2017. Subjectification and intersubjectification in the analysis of the Polish adverb niestety 'unfortunately/regrettably'. Crossroads. A Journal of English Studies 17, 9-29.

Prillop, Külli, Tiit Hennoste, Külli Habicht, Helle Metslang 2021. Ei saa me läbi „Pragmaatika“ korpuseta. Korpuspragmaatika ja pragmaatikakorpus. - Mäetagused (ilmumas).

Reinsalu, Riina 2019. Juhendavad haldustekstid žanriteoreetilises raamistikus. (= Dissertationes philologiae estonicae universitatis Tartuensis 44.) Tartu: Tartu Ülikooli Kirjastus.

Rühlemann, Christoph 2007. Conversation in Context: A Corpus-Driven Approach. London: Continuum.

Traugott, Elizabeth Closs 2003. From subjectification to intersubjectification. - Motives for Language Change. Ed. Raymond Hickey. Cam- 
bridge: Cambridge University Press, 124-139. https://doi.org/10.1017/ CBO9780511486937.009

Traugott, Elizabeth Closs 2010. (Inter)subjectivity and (inter)subjectification: A reassessment. - Subjectification, Intersubjectification and Grammaticalization. Ed. by Kristin Davidse, Lieven Vandelanotte, Hubert Cuyckens. Berlin, New York: De Gruyter Mouton, 29-74. https://doi. org/10.1515/9783110226102.1.29

Tüüts, Laura, Reili Argus 2016. Episteemilise modaalsuse leksikaalsete väljendusvahendite tajumisest: arvatavasti, äkki ja võib-olla. - Eesti ja soome-ugri keeleteaduse ajakiri. Journal of Estonian and Finno-Ugric Linguistics 7 (2), 187-208. https://doi.org/10.12697/jeful.2016.7.2.08

Valdmets, Annika 2013. Modal particles, discourse markers, and adverbs with lt-suffix in Estonian. - Discourse Markers and Modal Particles: Categorization and Description. Ed. by Liesbeth Degand, Bert Cornillie, Paola Pietrandrea. (= Pragmatics \& Beyond New Series 234.) Amsterdam, Philadelphia: John Benjamins Publishing Company, 107-132. https:// doi.org/10.1075/pbns.234.05val

Valdmets, Annika, Külli Habicht 2013. Episteemilistest modaalpartiklitest eesti kirjakeeles. - Eesti ja soome-ugri keeleteaduse ajakiri. Journal of Estonian and Finno-Ugric Linguistics 4 (1), 205-222. https://doi. org/10.12697/jeful.2013.4.1.12

Virroja, Kelly 2020. Episteemilise modaalsuse markerite kasutusfunktsioonid poliitilises vestlussaates „Esimene stuudio“. Bakalaureusetöö. Tallinn: Tallinna Ülikool.

Waksler, Rachelle 2012. Super, uber, so and totally: Over-the-top intensification to mark subjectivity in colloquial discourse. - Subjectivity in Language and Discourse. Ed. by Nicole Baumgarten, Inke Du Bois, Juliane House. Leiden: Brill, 17-31. http://dx.doi.org/10.1163/9789004261921_003

\section{Võrgumaterjalid}

EKSS = Eesti keele seletav sõnaraamat. http://www.eki.ee/dict/ekss/ (20.03. 2021).

ENC19 = Jelena Kallas, Kristina Koppel 2020. Eesti keele ühendkorpus 2019. Eesti Keeleressursside Keskus. https://doi. org/10.15155/3-00-00000000-0000-08489L (15.03.2021).

Keeleveeb. https://www.keeleveeb.ee/ (21.03.2021).

Suulise eesti keele korpus. https://keeleressursid.ee/et/220-suulise-eesti-keelekorpus (21.03.2021).

Sõnaveeb $=$ EKI ühendsõnastik 2020. Eesti Keele Instituut. https://sonaveeb.ee (20.03.2021). 


\title{
The use of six (inter)subjectivity particles in Estonian registers
}

\author{
TIIT HENNOSTE, HELLE METSLANG, \\ KÜLLI HABICHT, KÜLLI PRILLOP
}

The article analyzes the usage of three epistemic particles (vist, ilmselt, tegelikult) and three attitude particles (onneks, kahjuks, paraku) in texts belonging to different registers of Estonian: spoken interaction (institutional and everyday), online texts (instant messaging and comments), printed texts (prose fiction, journalism, and academic texts). The research material comes from the Keeleveeb portal and the corpora compiled in the project PRG341 "Pragmatics overwrites grammar: subjectivity and intersubjectivity in different registers and genres of Estonian". The study combines descriptive statistics with qualitative semantic and pragmatic analysis of the particles, comparing the frequency of usage of particles in different registers and exploring the possible semantic/pragmatic motivations underlying the frequency data.

The research results broadly confirm the statistical picture obtained from similar studies done on other languages. Particles are used especially often in everyday interaction and quite rarely in journalism and academic texts. Verbal interaction, online comment sections and fiction fall between these two extremes. However, the analysis also reveals that this sort of generalizing overview fails to adequately describe the phenomena under investigation.

First, the typical approach in register analysis, wherein epistemic and attitude particles are taken together as one group, is not appropriate. Different particles behave differently and should be analyzed individually. Only by doing this is it possible to determine the similarities and differences between particles.

Second, the oppositions hitherto proposed as factors capable of explaining the differences in usage frequency between particles (e.g. dialogue/monologue, spontaneous/edited, everyday/public) do indeed work, but only within certain boundaries. They can explain the variation in frequency of some but not all particles, and they can explain some but not all of the differences. We have identified additional factors and created a narrower classification of the previously known factors. Third, the variation in usage frequency of certain particles may itself be a useful criterion for distinguishing different registers. This is true primarily of neutral and widely used particles. Of the particles analyzed in the present study, 
the most appropriate for this purpose are vist, expressing uncertain knowledge, and the contrast-marking particle tegelikult.

Keywords: Estonian language, corpus pragmatics, particles, (inter)subjectivity, registers, variation

Tiit Hennoste, tiit.hennoste@ut.ee Helle Metslang, helle.metslang@ut.ee Külli Habicht, kulli.habicht@ut.ee Külli Prillop, kulli.prillop@ut.ee

Eesti ja üldkeeleteaduse instituut Tartu Ülikool Jakobi 2

51014 Tartu 